Studies in African Linguistics

Volume 25, Number 2, 1996

\title{
TONAL FEET AND THE ADAPTATION OF ENGLISH BORROWINGS INTO HAUSA*
}

\author{
W. R. Leben \\ Stanford University
}

This paper investigates how Hausa places a tonal interpretation on stress in English borrowings. A key intermediary in this process is the tonal foot, which is maximally disyllabic. Tonal feet are of two kinds, in complementary distribution in the data. One is interpreted as HL, or falling-toned, the other as High-toned. The analysis represents a significant advance over the less highly structured view that a simple substitution algorithm replaces stresses with tones, e.g., High tone for stressed syllables and Low tone for unstressed. This provides a boost for the status of the tonal foot as a prosodic constituent. The analysis also has implications for Hausa non-loan word phonology in that it suggests a natural reinterpretation of claims made by Newman and Jaggar [1989].

\section{Introduction}

This paper investigates how Hausa interprets English borrowings tonally. Hausa has High and Low lexical tones but no phonological stress, while English has no lexical tones but quite an intricate system of lexical stress. The data for this paper are 335 examples of English borrowings from Roxana Newman's English-Hausa dictionary [Newman 1990] and from a list compiled by Abdullahi Bature. Added to these are another dozen words ending in falling tones supplied by Paul Newman. I follow the standard practice of marking Low tones for Hausa with a grave accent, Falling tones with a circumflex accent, and leaving High tones unmarked.

The main factor goveming tone in Hausa borrowings from English is the position of main stress in the English source word (compare gàràntiii 'guarantee'

* I am grateful to my colleagues Abdullahi Bature and Paul Newman for sharing their data on Hausa borrowed words and to Firmin Ahoua for giving a careful reading and suggesting changes. I am also indebted to an anonymous reviewer for extremely valuable suggestions for the analysis. 
vs. gaadinà 'gardener'). In most cases, English main stress is interpreted as a High prominence peak in Hausa, as shown by the examples in (1).

(1) a.

$\begin{array}{ll}\text { soojà } & \text { 'soldier' } \\ \text { faakìn } & \text { 'parking' } \\ \text { ciizàl } & \text { 'chisel' } \\ \text { oofis } & \text { 'office' } \\ \text { raakèt } & \text { 'racket' }\end{array}$

b. (L)-L-HL

ràsît

kàsêt

ràfàlîi, làfàrîi

tànjàrîn

'receipt'
'cassette'
'referee'
'tangerine'

c. L-H-L

simintì

kàmashòo

ràkoodàa

kwàmandàa

$$
\begin{aligned}
& \text { 'cement' } \\
& \text { 'commission' } \\
& \text { 'recorder' } \\
& \text { 'commander' }
\end{aligned}
$$

The examples in (1a) are the simplest. Disyllabic English words with initial main stress tend overwhelmingly to be interpreted as $\mathrm{H}-\mathrm{L}$ in Hausa. The examples in (1b) illustrate how English words with final stress are normally interpreted. The final syllable is HL, and all preceding syllables are L. If the English word is stressed on the final syllable and an extra vowel is added at the end in its borrowed form, as with (1c) simintii 'cement', then the word receives a penultimate $\mathrm{H}$ tone, like the remaining words in (1c), whose English sources have penultimate stress, while the remaining syllables are L.

But it would be very wrong to conclude from this that English stress corresponds to Hausa $\mathrm{H}$, and that other syllables are rendered as $\mathrm{L}$. This would not generalize properly to most Hausa words other than those in the narrow categories in (1). For one thing, Hausa interprets some English words as having two stresses, as in (2), where two $\mathrm{H}$ tones appear, in each case followed by a $\mathrm{L}$ tone.
a. caajì oofis
'charge office'
b. fasà oofis
'post office'
c. hedimastàa
'headmaster'
d. helikaftàa
'helicopter'
e. iyàakwàndishìn
'air condition'
f. laasifinikàa
'loud speaker'
g. tânkiifàa
'timekeeper' 
These examples happen to be analyzed in English as compounds, ${ }^{1}$ but the data in (3), which behave identically, show that it is not English compound structure, but rather what is interpreted as stress to the right of main stress, that determines the behavior of these words. We see from (3a,b,c,f) that a syllable of the form $\mathrm{CVt}$ to the right of main stress (where V can be either long or short) is frequently interpreted as stressed, even though English speakers in general do not perceive any stress on the final syllables of these words.

\section{(3)}
a. asibitì
b. caakùleeti
c. kirsìmatì
d. kultibeetàa
e. laabùraarèe
f. singìleetì
g. sùkoolàshîf

'hospital'

'chocolate'

'Christmas'

'cultivator'

'library'

'singlet'

'scholarship'

The English source words in (2) and (3) all begin with main stress. In (3g), the English cluster [sk], which is not permissible in Hausa, undergoes epenthesis, and the epenthetic vowel $[\mathrm{u}]$ becomes Low-toned by a process to be described below. In all but one of these examples, the English main stress is rendered in Hausa as a High tone. The subsequent secondary stress is also rendered in Hausa as a High tone, as is any syllable of the form $\mathrm{CVt}$, where $\mathrm{t}$ represents the consonant t. Examples (2a) through (2d) have a secondary stress on the penultimate syllable, which is rendered by a Hausa penultimate High tone.

Note that Hausa inserts a vowel to make the second syllable of (2f) laasifiikàa 'loudspeaker' but does not do this in ( $2 \mathrm{~g}$ ) tânkiifàa 'timekeeper'. This is because the epenthesis rule is govemed by the syllable structure constraints of Hausa, which permit the CVC of tân to be interpreted as a syllable but not the CVVC sequence laas.

\section{Tonal feet}

Example ( $2 \mathrm{~g})$ tânkiifàa is particularly revealing, because it shows that HL can be inserted even on a single syllable, a sign that stress is not simply interpreted as a High tone. The same can be said for the final stressed cases in (1b) above. What unites these cases is that there is a single syllable that must bear a HL sequence. This suggests that the Hausa interpret English stress not as a High tone but as a HL sequence. It also suggests that this tonal interpretation applies not to the stressed syllable per se but rather to units that may contain one syllable, e.g., the first syllable of $(2 \mathrm{~g})$ tânkiifàa, as well as to units containing two syllables, like

1'Helicopter' is not etymologically a compound, but a common naive analysis treats it as having the compound pseudo-element 'copter'. 
the last two syllables of tânkiifàa. I will refer to such units as tonal feet. Zec [1994] introduces the term to account for Serbo-Croatian tone and stress. Here, where English stress is being interpreted tonally, the notion comes in very handy.

Examples from (1) have just one tonal foot, while those in (2) and (3) have two, as shown in (4), with tonal feet delimited by square brackets.

(4)

$\begin{array}{ll}\text { [soojà] } & \text { 'soldier' (1a) } \\ \text { rà[sî̀t] } & \text { 'receipt' (1b) } \\ \text { sì[mintìi] } & \text { 'cement' (1c) } \\ \text { [caajì] [oofis] } & \text { 'charge office' (2) } \\ \text { [tân][kiifàa] } & \text { 'timekeeper (2) } \\ \text { [asì][bitì] } & \text { 'hospital' (3) }\end{array}$

These examples illustrate that tonal feet begin with a "stressed" syllable and are exactly two syllables long in most cases. They are one syllable long if the foot begins with the final syllable of the word, as in rà [sît], or if the foot is immediately followed by another foot, as in [tân][kiifàa]. Thus, here are the basic characteristics of tonal foot formation in Hausa borrowings from English:

(5) Tonal Foot Formation

a. The left edge of the tonal foot coincides with what is interpreted as stress in English. This includes main stress, secondary stress, and syllables of the from $\mathrm{CV} t$.

b. The tonal foot is binary wherever possible. However, tonal feet do not overlap. If a domain includes the left edge of a tonal foot, then it cannot serve as the right edge of another tonal foot.

If secondary stress is to the left of English main stress, then the secondary stress tends to be ignored in foot formation, as in the examples in (6), which are treated as parallel to si[mintii], but with additional unfooted syllables on the left.

(6) màntà[leetàa] 'mentholatum'
fùròofà[gandàa] 'propaganda'

On the other hand, sometimes main stress in English is ignored when there is a secondary stress to the right. In (7) are examples that would be expected to behave like those in (2) and (3), but instead behave like those in (6). The data in (2), (3), and (7) exhaust the examples of this type in the corpus. Examples of the pattern of (2) and (3) outnumber those in (7) by two to one. 


\begin{tabular}{|c|c|}
\hline $\begin{array}{l}\text { kàafìreetòo } \\
\text { kwàtàmastàa } \\
\text { màkùròofôo } \\
\text { òogàneezàa } \\
\text { sùkkùdireebàa } \\
\text { gwàmnà-janar } \\
\text { kàtàfiilàa } \\
\text { tàafireetàa }\end{array}$ & $\begin{array}{l}\text { 'carburetor' } \\
\text { 'quartermaster' } \\
\text { 'microphone' } \\
\text { 'organizer' } \\
\text { 'screw driver' } \\
\text { 'governor-general' } \\
\text { 'Caterpillar tractor' } \\
\text { 'typewriter' }\end{array}$ \\
\hline
\end{tabular}

The other generalization that can be made about the tonal feet posited thus far is that they are assigned the tone pattern HL. Evidence for an additional tone pattern will be presented in the next section.

One word whose pattern is not predicted correctly is laskoofùr 'lance corporal'. One would expect the first syllable to have either a falling tone, as in tânkiifàa, or a Low tone, as in sàamanjàa 'sergeant major' .

\section{Another kind of tonal foot}

Disyllabic English words with initial stress are ordinarily rendered in Hausa with the pattern HL, as seen in (1a). This makes it tempting to expect a simple correspondence between stress and tone, with High tone corresponding to English stress on the first syllable of a foot, and Low tone equaling stresslessness on the second syllable of a foot. But this correspondence is far from exact. English stress does not always correlate with Hausa High tone, as shown by examples like kàlandàa 'calendar', sàmfaifàa 'sand paper', sìlimàa 'cinema', and sìniimàa, 'cinema'. These examples also show that stresslessness does not always correspond to Low tone. The same is also shown by the examples in (8). They constitute a somewhat diverse group because they correspond to English words as short as two syllables and as long as four. But they share the key property of having two successive High-toned syllables in Hausa, against only one stressed syllable in the English source. Associating Low tone with stresslessness would result in forms such as those in the middle column, which are not attested.

baasukùr
fankeekè2
gwabnatì
hankicì
kaabeejì

*baasùkùr
*fankèekè
*gwabnàtì
*hankicì
*kaabèejì

'bicycle'

'pancake'

'government'

'handkerchief'

'cabbage'

2 This form is from Bature's list. Newman [1990] gives fankèekè, with the tone pattern HLL, which is anomalous, both in the present account and, as far as I can tell, in relation to the remaining borrowed words in that source.

3 This form is from Bature's list. Newman [1990] gives gwamnati. 
(8) continued

kaafintàa
kwalaràa
kwalbatì
kwaleej̀̀
kyamaràa
laasiisì
maaleejì
maasinjà
màkaanikèe
manajà4
ministàa
nàajeeriyàa
raskwanàa
reediyòo
sàkàteeriyàa
taafintà
warantì

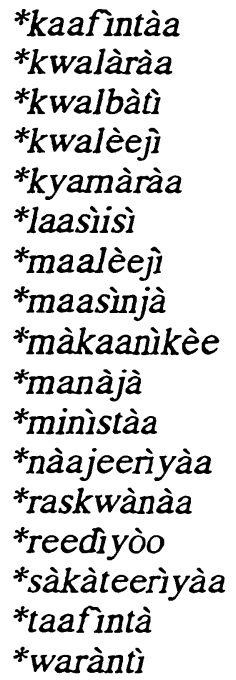

'carpenter'

'cholera'

'culvert'

'college'

'camera'

'license'

'mileage'

'messenger'

'mechanic'

'manager'

'minister'

'Nigeria'

'ready reckoner'

'radio'

'secretariat'

'interpreter'

'warrant'

These cases bring up a new generalization about the tonal interpretation of English stress. To find out what it is, let us apply the rules of tonal foot formation from (5) to the cases in (8). This results in the foot structures in (9).

(9)

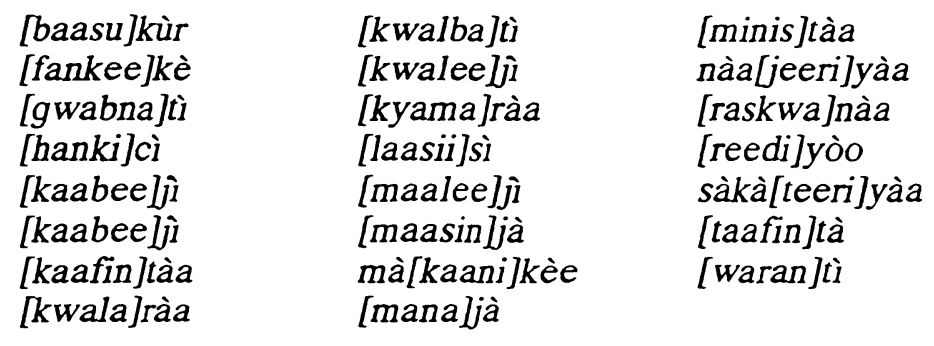

The striking tonal generalization in (9) is that everything within the foot is High, while everything outside the foot is Low.

It is easy to reconcile this generalization with what we have seen earlier. The tonal feet seen earlier, which were HL, are in complementary distribution with those in (9). Those in (9) occur before unfooted material, while those in (4) and (6) occur either word-finally or before another foot. Representative examples appear in (10). The distribution of $\mathrm{H}$ vs. HL in these cases suggests the rule formulated in (11).

4 This form is from Bature's list. Newman [1990] gives manajàa, with a long final vowel. 
(10) [soojà]

rà [sît]

sìmintii]

[tân][kiifàa]

[asi]][bitì]

fùròofà [gandàa]

[maasin]jà

nàa[jeeri]yàa

(11) Tone assignment

tonal foot $>\mathrm{H}$ before unfooted material;

tonal foot $>\mathrm{HL}$ elsewhere

By the standard rules of tone association of autosegmental phonology stated in (12) (Goldsmith [1979], as modified by Pulleyblank [1986]), we get the associations in (13).

(12) i. Within a tonal foot, assign the first tone to the first TBU, the second to the second, and so on.

ii. Within a tonal foot, every TBU must have a tone, and every tone must be assigned to a TBU.

iii. Association lines do not cross.

(13)

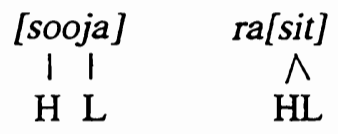

[asi][biti] furoofa[gandaa] I I II

$\mathrm{H} \mathrm{L} \mathrm{HL}$

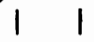

$\mathrm{H}$ L

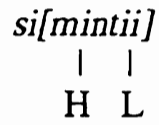

[maasin]ja

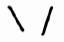

$\mathrm{H}$ [tan][kiifaa]

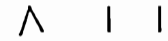

HL H L

Since the default tone is L, the result will be the tone patterns in (14).

$\begin{array}{cc}\text { [sooja] } & \text { ra[sit] } \\ 1 \mathrm{I} & 1 \wedge \\ \mathrm{H} \mathrm{L} & \mathrm{L} \mathrm{HL}\end{array}$

si[mintii]

L $\mathrm{H}$ L

naa[jeeri]yaa

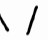

$\mathrm{H}$

\begin{tabular}{ccccccc} 
[asi][bit] & \multicolumn{3}{c}{ furoofa[gandaa] } & [maasin]ja & \multicolumn{3}{c}{ naa[jeeri]yaa } \\
I I II & I I I I I & I / I & I / / I \\
H L HL & L L L H L & H & L & L H & L
\end{tabular}


We may trace the HL Hausa feet to the corresponding English constituents with normal falling intonation. Interestingly, though, Hausa also includes an additional kind of foot with a level High tone.

\section{Independent evidence}

We have yet to motivate an account of tonal assignment to epenthetic vowels, but, as we will see, the analysis outlined above correctly predicts the tonal realizations of many different borrowed forms containing epenthetic vowels. Consider the penultimate vowels in (15), which all behave similarly.

\begin{tabular}{|c|c|}
\hline $\begin{array}{l}\text { àsambùlèe } \\
\text { askìrinn } \\
\text { caakùlèt } \\
\text { coocìlàn5 } \\
\text { disfansàrèe } \\
\text { firaamàrèe } \\
\text { fursùnà } \\
\text { ingìlà } \\
\text { lootàrèe } \\
\text { naasàrèe } \\
\text { reelùwèe } \\
\text { sigìnà } \\
\text { talqìràm }\end{array}$ & $\begin{array}{l}\text { 'assembly', } \\
\text { 'ice cream' } \\
\text { 'chocolate' } \\
\text { 'torch light' } \\
\text { 'dispensary' } \\
\text { 'primary school' } \\
\text { 'prisoner' } \\
\text { 'England' } \\
\text { 'lottery' } \\
\text { 'nursery' } \\
\text { 'railway' } \\
\text { 'turn signal' } \\
\text { 'telegram' }\end{array}$ \\
\hline
\end{tabular}

The penultimate vowel of askìrìn, caakùlèt, coocìlàn, ingìla, reelùwèe, sigìnà, and talgiràm is clearly epenthetic. The same can perhaps be said of the corresponding vowels of fursùna, lootàrèe, and naasàrèe, given that British English was the likely model for these words.

For these examples, we need to consider whether Tonal Foot Formation applies to the output of epenthesis or whether epenthesis applies only after the construc-tion of tonal feet and assignment of tone.

If Hausa feet were built on the epenthesized structures, they would resemble the ones in (9) that did not undergo epenthesis. The first two syllables would be interpreted as a tonal foot. Because it is followed by an unfooted syllable, the tonal foot would be $\mathrm{H}$, and the unfooted syllable would be made $\mathrm{L}$ by default. The sample in (16) illustrates an incorrect derivation.

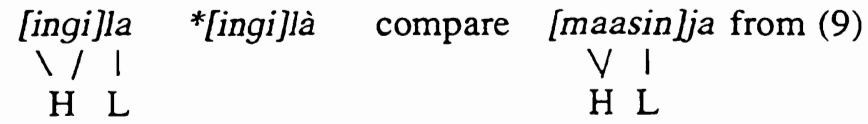

${ }^{5}$ This form is from Bature's list. Newman [1990] gives toocilàn, with the same tone pattern. 
But this result is avoided by building Hausa foot structure directly onto the English-based model before epenthesis applies, as in (17).

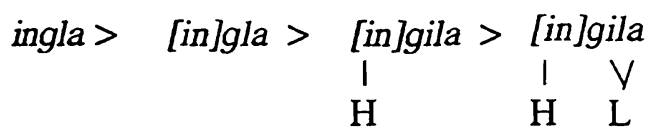

In general, then, Foot Formation applies to the unepenthesized structures. There are, however, a few special cases that require special treatment. The word likità 'doctor' has exactly the tone pattern that we wished to avoid in (16), but as an anonymous reviewer has noted, the segmental shape is also anomalous if we regard this item as having been borrowed directly from English. A more plausible source of this word is a language such as Yoruba, through which words of English origin like kwabòo 'penny' (from 'copper'), sulèe 'shilling', and tiitii 'street' came into Hausa. Two other entries on Bature's list, asimàa6 'asthma' and kitikàa 'kit car' also have this tone pattern. likita, with many segmental differences distinguishing it from the apparent source word 'doctor', no doubt has become a separate Hausa lexical entry. If its three syllables are underlying, then the analysis of words in (9) like maasinjà would predict the HHL pattern attested on likita. It is not clear, however, why this happens with asimàa and kitikàa.

Before we examine how Hausa treats epenthetic vowels in initial syllables, it is instructive to observe first how two distinct English stress patterns give rise to LHL in Hausa borrowings.

\section{The special problem of LHL words}

Consider the two sets of LHL words in (18)-(19) in relation to their English sources. The set in (18) is an exhaustive list of the LHL words in the corpus that correspond to an English word with no stress on the first syllable and main stress on the second syllable. ${ }^{7}$ These words are correctly described by the principles in (5), (11), and Default Low Insertion, as in the derivation in (20).

${ }^{6}$ This form is from Bature's list. Newman [1990] gives asmàa, with no epenthetic vowel.

7 A related but somewhat special case is kàlandàa 'calendar', which is apparently interpreted as if it had main stress on the second syllable in English rather than the first. Perhaps the heavy second syllable following a light initial syllable is responsible. However, this explanation does not account for silimàa 'cinema' (from Newman's [1990] dictionary), which exhibits the same shift. Interestingly, Paul Newman provides a variant siniimàa whose second syllable is lengthened in Hausa. 
(18) àkantàa

dàarakta

fàrfeelàa

fòomeekàa

kàashiyàa

kàmashòo

kwàmandàa

kwàmfyuutàa

làftanàn

ràkoodàa

sùfeetòo

sìrinjìi

tiyaatàa

(19) kàlandàa

sàmfaifàa

silimàa

sìniimàa 'accountant'

'director'

'propeller'

'formica'

'cashier'

'commission'

'commander'

'computer'

'lieutenant'

'recorder'

'inspector'

'syringe'

'theatre'

(20) a[kantaa] a[kantaa] a[kantaa]

'calendar'

'sand paper'

'cinema'

'cinema'

The cases in (19) are anomalous. Judging from those in (8) and (9), these ought to be High on the first two syllables, like [mana]jà and [minis] tàa, since their English models have initial stress. The foot structure ought to be as in (21), and, because the foot is non-final in the word, it ought to have a level High tone. Certainly, we would not expect it to be Low-High, as is actually attested, since this tone pattern has not been found on any other foot of Hausa borrowings.

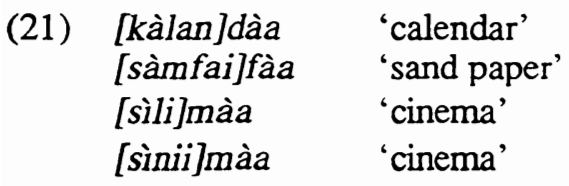

The explanation for these forms is not readily apparent, but see footnote 8 for a suggestion. 


\section{Epenthetic vowels in initial syllables}

To motivate an analysis of words whose initial syllable has an epenthetic vowel, it is useful to compare them to words that have no epenthetic vowels at all. A subset of such words from (18) is provided in (22) below.

$\begin{array}{ll}\text { (22) àkantàa } & \text { 'accountant' } \\ \text { dàarakta } & \text { 'director' } \\ \text { fàrfeelàa } & \text { 'propeller' } \\ \text { fòomeekàa } & \text { 'formica' } \\ \text { kàashiyàa } & \text { 'cashier' } \\ \text { kàmashòo } & \text { 'commission' } \\ \text { kwàmandàa } & \text { 'commander' } \\ \text { kwàmfyuutàa } & \text { 'computer' } \\ \text { làftanàn } & \text { 'lieutenant' } \\ \text { ràkoodàa } & \text { 'recorder' }\end{array}$

For words whose first syllable has an epenthetic vowel in Hausa, the corpus shows two patterns, illustrated in the two sets of data in (23) and (24). Most entries appear both on Bature's list and in Newman's [1990] dictionary. In case of discrepancies, Bature's (more recent) entry is listed in the main column of the table, Newman's variant in braces to the right. Differences are omitted if they do not involve tone and probably involve transcription practice rather than linguistic contrasts (viz. short $i$ vs. ii).

\begin{tabular}{|c|c|c|}
\hline $\begin{array}{l}\text { bùroodì } \\
\text { bùruushìi } \\
\text { gìlaashìi } \\
\text { sàfayàa } \\
\text { sifaaanàa } \\
\text { sifirìt } \\
\text { sikaawùt } \\
\text { sikeefli } \\
\text { sittaacì } \\
\text { sitaatàa } \\
\text { sitaatìi } \\
\text { sitamfii } \\
\text { sufeetòo8 }\end{array}$ & $\begin{array}{l}\text { 'bread' } \\
\text { 'brush' } \\
\text { 'glass' } \\
\text { 'spare' } \\
\text { 'spanner' } \\
\text { 'spirit' } \\
\text { 'scout' } \\
\text { 'scale' } \\
\text { 'starch', } \\
\text { 'starter' } \\
\text { 'starch' } \\
\text { 'stamp' } \\
\text { 'inspector' }\end{array}$ & $\begin{array}{l}\begin{array}{l}\text { buroodi }\} \\
\text { \{bùrooshìi }\}\end{array} \\
\{\text { sàfiyàa }\}\end{array}$ \\
\hline
\end{tabular}

8 An anonymous reviewer has suggested that this word has an epenthetic first vowel, based on the putative English input 'spector, with its first syllable dropped. This would explain the considerable leap from the English beginning ins to the Hausa one, su.. Other examples, e.g. tiyaatàa 'theatre', could be interpreted in a similar way (i.e. as coming from a truncated English input form with initial theta followed by the glide $y$, with no vowel in between). The beauty of this explanation is 


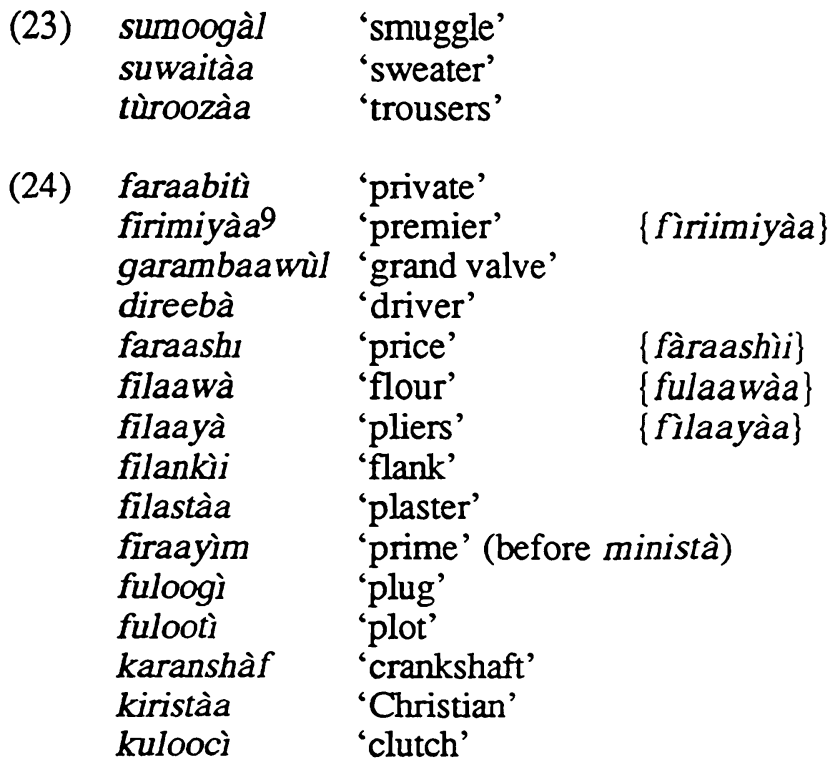

As an anonymous reviewer has pointed out, a preponderance of words begin with voiceless coronals in the first list and absolutely none do in the second. We would not be far off if we phrased the generalization as follows: words with epenthetic first vowels have a Low tone on the first syllable if the initial consonant is a voiceless coronal and a High tone otherwise. This would not explain the pronunciations bùroodì, bùruushì , and gìlaashìi. However, the first of these does have the LHL variant predicted by this rule, and it would be difficult to rule out the possibility of alternate LHL forms for the other two as well. Perhaps there are competing forces at work in these cases: the tendency to assign High tone to toneless syllables whose onsets are sounds other than voiceless

that it helps to bridge the gap between the English original, which tends to have initial stress in British English, and the Hausa, which looks on the surface as if it came from a model with penultimate stress. The shift of stress from the first to the second syllable could be explained if the first syllable's vowel had been perceived as the glide $y$, with the initial stress shifted to the new initial syllable, a fused version of the first and second syllables of the original. The theta-y cluster would then be understandably broken up with an epenthetic vowel, which, as we will see, would receive a Low tone. As the reviewer goes on to suggest, one might even entertain similar solutions for the problematic stress shift cases cited above, kàlandàa 'calendar', sàmfaifàa 'sand paper', silimàa 'cinema', siniimàa 'cinema'.

9 It is possible that the model for Newman's [1990] form- furiimiyàa-is the British pronunciation with stress on the first syllable: PREmier. This would explain why the form behaves tonally like reediyoo, aside from the initial syllable $f i$, which results from epenthesis and the change of English $p$ to Hausa $f$, with a Low default tone on this syllable, as with most of Newman's other examples beginning in $f$. Thus, the foot structure would be fi[riimi]yàa. 
coronals (as in búroodi), as against the tendency to assign Low tone to syllables containing epenthetic vowels after voiced obstruents (as in bùroodi).

\section{Epenthetic final vowels}

We may now return to cases like simintii in (1c). In section 2, this word was assumed to have the foot structure si[mintii]. If the final vowel is epenthetic, the assumption that foot formation precedes any kind of epenthesis will lead us to posit a different derivation for this word, but with the same output as before.

(25)

$$
\begin{array}{ll}
\text { Fimint }>\text { Fi[min]t }>\text { Epenthesis } & \text { Tone Assign. } \\
\text { si[min]tii }>\text { si[min]tii } & >\text { Default L } \\
\text { si[min]tii } & \text { L H L L }
\end{array}
$$

Thus, one is free to analyze the final vowel as epenthetic synchronically or not, without any tonal ramifications.

\section{Excursus: Borrowings ending in two Low tones}

This account provides some perspective on a point of Hausa tonology raised by Newman and Jaggar [1989]. About half the forms in (15) end in long vowels. Those that end this way are repeated below in (26).

$\begin{array}{ll}\text { (26) àsambùlèe } & \text { 'assembly' } \\ \text { disfansàrèe } & \text { 'dispensary' } \\ \text { firaamàrèe } & \text { 'primary school' } \\ \text { lootàrèe } & \text { 'lottery' } \\ \text { naasàrèe } & \text { 'nursery' } \\ \text { reelùwèe } & \text { 'railway' }\end{array}$

A possible derivation is shown in (27).

(27)

Tone Assign. Epenthesis Default L

$a[$ sam $] b l e e>a[$ sam]blee $>\quad a[$ sam $]$ bulee $>a[$ sam $] b u l e e$

$\mathrm{H} \quad \mathrm{H} \quad \mathrm{L} \mathrm{H}$ L L

After considering a variety of Hausa examples, including several in (26), Newman and Jaggar [1989] reject the rule in (28), from Leben [1971].

(28) Low Tone Raising

$$
\mathrm{L} \underset{\text { [+Long] }}{\mathrm{L}} \# \rightarrow \mathrm{L} \underset{[+ \text { Long] }}{\mathrm{H}} \#
$$


Low Tone Raising was proposed by Leben [1971] and Leben and Bagari [1975] to explain a number of morphophonemic alternations in Hausa, as well as being widely evident from surface tonal patterns. Indeed, the effect of the rule can be seen in borrowings, since in comparison to words like simintii, where the final epenthetic vowel is Low and is preceded by a High tone, words like oofishii, whose final epenthetic vowel is preceded by a Low tone, get a High tone on the final syllable by the rule in (28). However, Newman and Jaggar [1989] note that forms like those in (26) do not undergo (27) and so regard them as counterexamples.

Yet something very regular seems to be going on here. The Low-toned penultimate vowels are all arguably epenthetic, a point made by Schuh [1989:258]. This is clearly so for reelùwèe and àsambulèe. The remainder all have an [r] at the beginning of their final syllable. This concentration of $[r]$ 's makes it possible to speculate that the vowel before [r] in the English source words was deleted, reduced, or fused with the following [r] sound, or was heard by Hausa speakers as being reduced in this way.

These words would then have a derivation parallel to (27), as shown in (29).

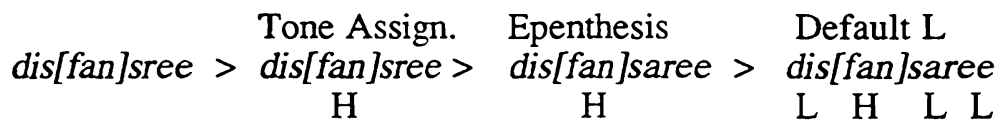

This account offers a reason why the borrowings cited by Newman and Jaggar [1989] escape the raising of their final syllable to High: the epenthesis rule that creates these forms applies after (28) Low Tone Raising. If we fully interpret the proposed inputs to Epenthesis tonally, they do not meet the environment of the rule, since there is just a single final Low-toned syllable rather than the required two: àsamblèe, disfansrèe etc.

Such an account seems quite plausible, considering that, as Newman and Jaggar [1989] allow, these forms are recent borrowings. Their connections with the English source words are no doubt obvious to Hausa speakers with a knowledge of the English source words, constantly reinforcing the "inserted" status of the epenthetic vowels in question. Rule (28), on the other hand, is a lexical rule in the sense of Kiparsky [1982], with an essentially morphophonemic function applying to established lexical items but not to newly coined ones. 10 This is supported by Newman and Jaggar's [1989] other findings. Of the seven other groups of "exceptions" that they list, all would more plausibly be viewed as the product of processes at the outer reaches of the lexical phonology or in the post-lexical

\footnotetext{
10 Newman and Jaggar [1989] say that it was presented in Leben [1971] as a rule "comparable to what today one might describe as a post-lexical rule." This is mistaken. Leben [1971] even noted a lexical exception and, though not forseeing the advent of lexical phonology ten years later, did entitle the article "The morphophonemics of tone in Hausa."
} 
phonology. Schuh [1989], in his critique of Newman and Jaggar's article, makes a similar point. Note that four of their groups involve reduplication in the formation of words with high emotional content: "semantically expressive" adjective plurals (fankamaa-fànkàmàa), ideophonic adjectives (daraa-dàràa), ideophonic adverbs (jagee-jàgèe), and ideophonic action nouns (rabaa-ràbàa). It is unsurprising that these act as a class, and it is equally unsurprising that this group does not include non-emotive constructions that involve clearly lexical processes of reduplication, such as the formation of the intensive of verbs by reduplicating CVC or the formation of certain adjectives by reduplicating CVC). Another group on their list are vowels lengthened utterance-finally in questions. There is no reason why these should undergo lexical rules. Slightly more interesting are a class of "alternative L-L imperatives" which they report to be quite common as alternatives to the standard L-H imperatives. Perhaps the case is not unlike the Hausa borrowings in (26) whose inserted vowels remain in speakers' consciousness because they continue to exist side-by-side with their English source words. Having the standard L-H imperative as a lexical model, perhaps Hausa speakers are able to derive the $\mathrm{L}-\mathrm{L}$ alternative as a more conscious process, one which understandably would escape a lexical tone rule because the alternative is not formed by a lexical process. The final case brought up by Newman and Jaggar [1989] adds two more exceptional adverbs, wàatàu/wàatòo 'that is to say' and Kàasàrai /Kàasàrèe 'contemptuously' to yàayàa/Kàakàa 'how', mentioned in the initial work of Leben [1971]. The latter group seems to include the only truly lexical exceptions on the list.

Incidentally, the analysis proposed for (26) automatically explains tone assignment to sakandàrèe 'secondary school'. Due to the extra post-stress syllable in the English model, this word has an epenthetic vowel two syllables after the English stressed syllable. Despite this difference, the analysis predicts its outome correctly, as the derivation in (30) demonstrates.

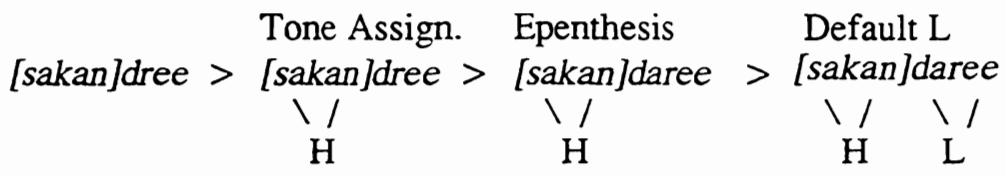

\section{Conclusions}

This analysis demonstrates the need for the tonal foot as a structural intermediary between English stress and Hausa tone. Without it, there is no obvious way to capture the complementarity between the High-Low and level High patterns that Hausa assigns. 
Epenthetic vowels receive different tonal interpretations depending on their position in the Hausa word. They do not receive a uniform tonal treatment in Hausa.

The analysis also has implications for Hausa non-loan word phonology, in that it suggests a natural reinterpretation of claims made by Newman and Jaggar [1989].

\section{REFERENCES}

Goldsmith, John A. 1979. Autosegmental Phonology. New York: Garland Press.

Kiparsky, Paul. 1982. "Lexical phonology and morphology." In I. S. Yang (ed.), Linguistics in the Morning Calm, Vol. 2, 3-91. Seoul: Hanshin.

Leben, W. R. 1971. "The morphophonemics of tone in Hausa." In C.-W. Kim and H. Stahlke (eds.), Papers in African Linguistics, pp. 201-218. Edmonton: Linguistic Research..

Leben, W. R. and D. M. Bagari. 1975. "A note on the base form of the Hausa verb." Studies in African Linguistics. 6:239-248.

Newman, Paul and Philip J. Jaggar. 1989. "Low Tone Raising in Hausa: A critical assessment." Studies in African Linguistics. 20:227-251.

Newman, Roxana Ma 1990. An English-Hausa Dictionary. New Haven: Yale University Press.

Pulleyblank, Douglas. 1986. Tone in Lexical Phonology. Dordrecht: Foris.

Schuh, Russell G. 1989. "The reality of Hausa 'Low Tone Raising': A response to Newman \& Jaggar." Studies in African Linguistics 20:253-262.

Zec, D. 1994. "Footed tones and tonal feet: Rhythmic constituency in a pitch accent language." Ms., Comell University.

Department of Linguistics

Stanford University

Stanford, CA 94305

leben@stanford.edu
[Received August 26, 1996; provisional acceptance October 21, 1996; final version accepted December 20, 1996] 